\title{
The Role of the Community Ownership and Management Strategy towards Sustainable Access to Water in Ghana (A Case of Nadowli District)
}

\author{
Nicholas Fielmua \\ Research Fellow, University for Development Studies \\ Centre for Continuing Education and Interdisciplinary Research (CCEIR) \\ P.O. Box 520, Wa Campus, Upper West Region, Ghana \\ Tel: 233-243-255-001Ｅ-mail: fielmua@yahoo.com
}

Received: April 14, 2011

Accepted: May 16, 2011

doi:10.5539/jsd.v4n3p174

\begin{abstract}
In rural Ghana, provision of water facilities adopts the demand driven approach and the facilities are community managed. This approach emerged because the supply driven and centralised system of providing water facilities could not sustain access to potable water especially in rural areas. The demand driven approach is expected to guarantee sustainability in access to water. In 1994, Ghana launched the National Community Water and Sanitation Programme with Community Management as a core strategy. This paper assesses the role of community ownership and management strategy towards access to water in the Nadowli District in Ghana. Data was collected through household interviews, focus group discussions and key informant interviews in 10 communities in the District. The findings showed that the community ownership and management strategy has improved access to potable water in Ghana and the Nadowli District in particular. As at December 2008, 88.2 per cent of the District population had access to potable water.
\end{abstract}

Keywords: Water, Access, Community Management, Ghana

\section{Introduction}

The central government and external support agencies were responsible for planning, constructing and maintaining rural water supplies, with little involvement of the private sector except for the foreign consulting firms hired to run projects and international contractors to drill boreholes (Salim, 2002). This system of water provision and management was not sustainable. This called for the need to involve communities in the process of acquisition and management of the water facilities. Community participation was therefore espoused as one of the key strategies of the International Drinking Water and Sanitation Decade (IDWSD) which spanned the 1981 - 1990 period (McCommon, Warner \& Yohalen, 1990).

It was however realised that community participation in water programmes was being limited to mobilisation of self-help labour or the organisation of local groups to ratify decisions made by project planners outside the community (Laryea, 1994). This narrow conception has very serious inherent limitations to successful implementation of rural water programmes. Thus, the emphasis was again shifted to community management. Present drinking water and sanitation policies assume that the facilities can and should be best managed by local user communities. It is expected that the so-called 'communal management' will guarantee the technical sustainability of the facilities as well as give more equal access to water (Eguavoen, 2006).

In response to the international agenda on water and sanitation, the water sector especially rural water, went through restructuring. In 1994, the operation of rural and small town water supplies moved from the then Ghana Water and Sewerage Cooperation (GWSC) to community management under the Community Water and Sanitation Division established within GWSC and charged with the responsibility for facilitating the community water supply sector. Subsequently, the Division was transformed into the Community Water and Sanitation Agency (CWSA) by an Act of Parliament, CWSA Act, Act 564 in 1998 with the mandate to facilitate the provision of safe drinking water and related sanitation services to rural communities and small towns in Ghana (CWSA, 2007a). The same Act of Parliament that established CWSA also transferred ownership and implementation responsibilities to districts and communities with the aim to increasing access to sustainable potable water. 
In line with the decentralisation policy of the country, the National Community Water and Sanitation Programme (NCWSP) represents a policy shift away from dependency on government for development towards reliance on user communities. The policy seeks to ensure sustainability of investment in water and sanitation by making beneficiary communities the primary focus. The NCWSP therefore adopted a Community Ownership and Management (COM) strategy under which community water and sanitation committees handle day-to-day maintenance and repair needs of the facility (CWSA, 2007a). The COM strategy is to ensure that there is adequate sustainable potable water supply to the communities.

\subsection{The Research problem}

District Assemblies are expected to structure project finances so that the Assembly pays 5 per cent, project grant covers 90 per cent and the remaining 5 per cent falls on the beneficiary community (although actual contributions vary due to different interpretations across projects). A study carried out by Water Aid (2005) had reservation on this approach in respect of equity principle. Accordingly, equity is compromised by the rules which are set for community water projects. The study indicated that while this requirement stems from the need to adopt a demand-responsive approach, its effect will worsen the plight of the poor. Again, while this 5 per cent rule seems to be functional in better-off regions, it is a constraint in Northern Ghana with its high poverty level (Eguavoen, 2008).

Not only does the 5 per cent rule make it difficult or impossible for poor people to gain access to safe water, it leaves them dependent on unsafe water sources with all the health implications (Water Aid, 2005). Similarly, Karikari (1996) espoused that the premium placed on community financial obligation might create obstacles for meeting the set objectives of providing the widest rural areas with safe water. This is because most settlements have very small populations, and many of these, particularly in the savannah zones, cannot afford the 5 per cent capital contribution towards safe water supply.

The traditional role that rural communities have been playing in the past with regard to development projects is that, they have always been on the receiving end and have therefore become spectators of their own development. This approach with its long history in Ghana, makes it difficult for rural communities to accept the concept of community management particularly with respect to ownership and hence responsibility for the system (Laryea, 1994). Improving access to potable water is critical to achieving favourable health outcomes, since in Ghana an estimated 70 per cent of all diseases are caused by lack of clean water and proper sanitation (Government of Ghana, 2006a). Health problems such as diarrhoea, skin diseases, acute eye infections, cholera and dysentery, typhoid and infectious hepatitis, trachoma and scabies are consequences of poor drinking water (Government of Ghana, 2006a). In 2006, it was reported that about 44.5 per cent and 12 per cent of all out-patients visit to health facilities in Ghana were the result of malaria and other water related diseases respectively (ibid).

The central issue remains as to what extent the approach has improved access to potable water in Ghana. It is on the basis of the above that, this paper seeks to assess the contribution of community ownership and management of water facilities towards improved access to potable water in rural Ghana. The Nadowli District was used as a case study.

\section{Conceptual Issues}

\subsection{Concept of Access to Water}

Though there are varying interpretations of water, the variations are the result of cultural, geographical and the context of a particular study. Water as used in this paper refers to safe water. The CWSA Act, 1998 (Act 564) on the other hand defines safe water as water of specified quality standard meant for drinking purposes. According to the WHO (1976), reasonable access to potable water in urban areas denotes a public fountain or tap not more than 200 meters from a house while in rural areas reasonable access implies that members of a household do not have to spend a disproportionate part of the day obtaining water. The WHO/UNICEF (2000) Joint Monitoring Programme describes reasonable access as the availability of at least 20 litres (five gallons) per person per day from a source within one kilometer of the user's dwelling. However, to the author, "disproportionate" as used by the WHO is subject to different interpretations. Access to safe drinking water in rural areas is defined by the CWSA to include supplies from boreholes delivering a minimum of 20 litres per person/day, serving at least 300 persons each within 500 meters of households being served (CWSA, 2007a). For the purpose of this paper, the CWSA definition of access to water is adopted.

\subsection{Basis of Community Ownership and Management}

Development efforts of many African countries immediately after independence saw an increasing extension of state authority in areas which had traditionally been the preserve of local custom and control (Korten, 1987). The 
result has largely weakened local capacity and a transfer of resources and power from local to national with a national treasury burden that is unable to deliver the expected services to the communities. In many countries, water was recognised as a public good and the governments undertook to cover all capital costs of investment (Maganga, and Butterworth, 2002). However, these early investments could not be maintained and many schemes fell into disrepair. These systems of service delivery do not promote local initiative. Consequently in the 1970s and early 1980 s, there was a move towards community participation (ibid).

At the same time, evidence is accumulating that properly supported communities have the ability and the willingness to manage their own water systems (Evans \& Appleton, 1993). This implies that state resources that were swallowed up in the provision and maintenance of ineffective services can thereby be diverted to a much more effective facilitating role, bringing greater cost-effectiveness and more widespread and sustainable benefits (ibid).

\subsection{Community Ownership and Management (COM)}

According to Conyers (1981), the United Nations report on community development states that: "implicit in the theory that has been built up in relation to community development is an organic and physical concept of community - a group in face-to-face contact, bound by common values and objectives, with a basic harmony of interest and aspirations". Three important criteria are considered in this definition. The first concept of community has a physical component. It implies that a group of people living in a geographical area and interacting with one another. Secondly, they have characteristics in common which enable them to be identified as a group. Finally, a community should have what Conyers (1981) described as "basic harmony of interest and aspirations" (p.126). The CWSA further divided the concept into small town (population above 2000) and small community (population below 2000) for the purpose of its operation.

\subsubsection{Community Ownership of the System}

Community ownership of a system emanates from two sides: (i) small town systems and boreholes built with the support of CWSA with 5-10 per cent contributions from District Assemblies (DAs) and community members to the investment costs, and (ii) systems transferred from Ghana Water Company Limited to DAs for community management. These are often governed by a memorandum of understanding (MOU) signed between GWCL and CWSA for those systems the former owned (Berkoh, Hirsch, Larbi, Leenen, Ntow, Jo Smet, Marjon. 2004). As part of the reforms in the water sector, including the Private Sector Participation (PSP) process in water, small town systems, numbering 124, were transferred from GWCL to the District Assemblies for community operation and management. This has led to an increase in the upper limit of small towns, much higher than the levels envisaged by the NCWSP and has drawn CWSA more towards the larger small town communities (CWSA, 2007b).

According to Hiroko (2008), the sense of ownership that the village water and sanitation entities have over their new facilities is in direct contrast with the understanding that the villagers used to have in the past. Initially, the implementers worked alone in identifying sites and constructing the schemes without the participation of the villagers. As such when the facilities broke down, the villagers did nothing to repair them apparently stating that they belonged to the implementer and not to them. That is why Maganga \& Butterworth (2002) emphasized that community ownership is a means of achieving sustainability through community investment and commitment to their schemes, and specifically through the mechanism of village water committees. In practice, membership of a pump community can be gained by the payment of either the initial community contribution or a later entrance fee. The entrance fee was not foreseen in management guidelines but is an innovative institution, which was created at the local level to cope with inabilities to contribute (Eguavoen, 2006).

\subsubsection{The Concept of Community Management}

According to WHO (1996), community management means that the beneficiaries of water supply and sanitation services have responsibility, authority and control over the development of their services. Responsibility implies that the community takes ownership of the system, with all its attendant obligations and benefits/liabilities whilst authority indicates that the community has the legitimate right to make decision about the system. Control implies that the community has the power to implement the decisions regarding the system. McGarry (1991) further indicated that because the community has the authority and responsibility for operation and maintenance, this will be more effective and efficient, leading to improved sustainability of the services. McCommon et al (1990) continued that the control element as contained in this definition distinguishes community participation (where the government and other institutions may have control) from community management (where the community definitely has control). It is therefore an establishment of a system in which full collaboration between government and community is essential, and in which neither is the dominant partner. Both should have clearly defined roles 
and each understands and accepts the role of the other. If this clarity is not achieved then community management may be impossible to implement (McGarry, 1991).

Community ownership and management however does not mean that community will not receive support from external sources. The community may receive support from government or other agencies in the form of subsidies, technical support and so on, but it must be the community itself that actually owns the system, makes the decisions on when to call for this support, and exercises control over access to the system (WHO, 1996). Community ownership and management (COM) is therefore a strategy that empowers communities through genuine partnership, to advocate for water and sanitation services. Rather than passive consumers, communities are able to actively participate in the entire process of acquisition and operation of the facilities. It is a model in which professionals are "on tap, not on top" (Brennan 1994). This implies that communities will have to elect water management committees that will be accountable for managing the water facilities.

\section{Data Collection Method}

The case study approach was adopted for this study. Yin (1984) defines the case study research method as an empirical inquiry that investigates a contemporary phenomenon within its real-life context; when the boundaries between phenomenon and context are not clearly evident; and in which multiple sources of evidence are used. When phenomena are essentially contemporary, which involves operating within specific contexts, then the case study method is appropriate. Similarly, as Norgaard (1994) emphasizes, the case study research is the preferred one when control on the subjects of the study is neither feasible nor desirable. Since in the case of this study, Community Management is the focal point, it is only within the everyday life context of the communities that valid observations and analyses can be made. The units of enquiry in this research include; the District Water and Sanitation Team, Water and Sanitation (WATSAN) Committees, Water and Sanitation Development Boards (WSDB) and Households. During the preliminary visit to the District, the communities were classified into three strata, namely; communities that have point sources (Boreholes), communities with Small Town Water System (STWS) and communities without any form of potable water.

\subsection{Sampling}

As noted by Soniya \& Howard (1997), in qualitative study of this nature, purposive sampling is the most suitable and should cover selected communities. For the purpose of this study, 10 communities were selected in consultation with the DWST. The three communities with STWSS in the District were part of the sample. The sampling of households in this study was informed by the United Nations description of a community as a "basic harmony of interest and aspiration" (Conyers, 1981). This is particularly important to planners because it means that the members of a community are likely to have similar views of current and future development in their area. Hence this definition was adopted for the study. However, to keep within the boundaries of scientific enquiry, three factors were considered; the level of confidence desired ( 95 per cent), the error tolerance level ( 5 per cent) and the proportion of the population with access to potable water in the District ( 88.2 per cent). The sample size was then determined using the following formula (Adapted from Kendie, 2002):

$\mathrm{N}=(\mathrm{z} / \mathrm{e})^{2}(\mathrm{p})(1-\mathrm{p})$, where:

$\mathrm{N}=$ sample size

$\mathrm{z}=$ standard score at $92 \%$ Confidence Level (1.96)

$\mathrm{e}=$ sampling error allowed $(0.05)$

$\mathrm{p}=$ proportion of population with access to potable water in the district $(88.2 \%)$

$\mathrm{N}=(1.76 / 0.08)^{2}(0.882)(0.118)=160$

Hence 160 persons (representing household heads or their spouses) were interviewed in the ten communities. The main data collection tools used include focus group discussion and semi-structured questionnaires. In all the ten communities, the households were randomly selected for the interview. The interviews focused on the household access to water, mode of payment for water services as well as the management strategies used in the communities. The data collected from both primary and secondary sources were then collated, synthesized and analyzed using both qualitative and quantitative approaches to draw valid conclusions and inferences.

\section{Results and Discussions}

\subsection{Access to Water Services at the National Level}

The NCWSP has made some progress since its launch in 1994. Accelerating the provision of safe water requires the construction/rehabilitation of water supply systems. According to GoG (2009), 12366 new boreholes were 
drilled and installed between 1994 and 2008 while 3928 boreholes were rehabilitated within the same period. Similarly, a total of 1467 new hand-dug-wells were constructed while 3928 hand-dug-wells were rehabilitated within 1994 and 2008. Since the inception of the NCWSP in 1994, 373 new pipe systems comprising 46 (12.3 per cent) small communities pipe systems (mechanised systems with limited distribution serving population up to 2000 ) and 327 (87.7 per cent) small town pipe systems. The small towns' piped systems have higher capacity in terms of water storage and distribution than the small community piped systems.

Capacity building of key actors in rural water delivery and management usually precedes the provision of the facilities. Between 1994 and 2006, the CWSA through its programmes trained 680 Hand Dug Wells (HDW) contractors, 1687 area mechanics and 20617 pump caretakers as part of its private sector capacity building towards improving access to water (CWSA, 2007a). In the Upper West Region, all the districts participated in the project. According to the World Bank (2005) completion report on CWSP II, District Assemblies effectively promoted projects and generated very high demand for sub-projects. Capacities of District Assembly staff were strengthened through training and equipment supply (computers, motor bikes, office supplies). All these are geared towards enhancing the District Assemblies role in improving access to water in rural areas.

This has improved access to water significantly as shown in Figure 1. With the implementation of Community Water and Sanitation Programmes (CWSP I and II), 795000 people (6 per cent of the total rural population) in Ghana were supplied with potable water (World Bank, 2008). In 1990, it was estimated that, 27 per cent of rural population had access to potable water. This increased to 30 per cent in 1999 and further to 52.86 per cent in 2006 .

\section{Insert Figure 1.}

Wide regional differences in population with access to safe drinking water also persist. In rural water coverage, access ranges from 76.76 per cent in the Upper West Region to 41.27 per cent in Western Region. As shown in Table 1, Central Region recorded the lowest (36.5 per cent) in access to water but was able to improve access considerable to 48.87 per cent in 2007. Western Region has experienced a continuous drop in access to water between 2005 and 2007. The region however improved slightly (by 0.34 per cent) in 2008 .

\section{Insert Table 1}

\subsection{Overview of the Nadowli District}

The Nadowli District of the Upper West Region is bordered on the south by Wa Municipal, west by Burkina Faso, north by Jirapa District and east by Sissala East and Wa East Districts. It covers a total land area of $2742.50 \mathrm{~km}^{2}$. The major stream, the Bakpong and several temporary streams flow into the Black Volta. Though water from these sources is not potable, households depend on them for laundry purposes thus reducing pressure on the potable water facilities. However, in the rainy season, they serve as sources of drinking water in instances where farmers stay on their farms throughout the season. Geologically, there are three main types of rocks- Birimian, Granite and Basement complex. Discussions with the Regional Engineer of CWSA revealed that these rocks, unlike the Voltaian rocks in Northern Region, hold considerable quantity of water, which can readily be made available for use by drilling of boreholes and sinking of wells.

According to the Ghana Statistical Service (2005), the District had a total population of 82716 in 2000 which can be projected to 93262 in 2008 using an annual growth rate of 1.5 per cent. The District has a population growth rate of 1.5 per cent per annum and a male/female ratio of 80:100 as compared with the national ratio of 98:100. The high proportion of women calls for specific policies to address women's concerns such as access to potable water. The general increase in population demands the provision of water facilities to meet the increasing demands.

The District is dominated by the agricultural sector which accounts for about 85 per cent of the labour force while commerce/service and industry (small scale) account for 14 per cent and 1 per cent of the labour force respectively. Agriculture is however subsistence in nature. In terms of household income, the mean annual income of the District is GH $\notin 480.00$ (US\$384.00) whereas the mean annual expenditure stands at GH $\not 504.00$ (US\$403.20). This shows a gap between income and expenditure, which is filled by remittances. This has implications for community contribution towards the provision of facilities such as water and sanitation. The survey confirmed this, as some communities sometimes rely on remittance from Politicians to finance operation and maintenance (O\&M) of water facilities. The major industrial activities include "Pito" (local alcoholic drink) brewing, groundnut oil extraction, shea butter processing and pottery. These activities account for 78.5 per cent of all industrial activities in the District and their operations rely on the availability of water.

At the District level, the District Water and Sanitation Team (DWST) is the main government body responsible for issues relating to water and sanitation. In terms of water and sanitation, the Social Services Sub Committee of the 
District Assembly approves the constitutions and tariffs of WSDB as well as monitors the activities of the DA social services delivery. However discussion with the DWST indicated that the monitoring role of the Sub Committee was weakly performed.

\subsection{Community Management Strategies in Practice}

With the community ownership and management, communities are responsible for all operation and maintenance (O\&M) related cost of the facilities. That is the sustainability of the facilities rest on the community. From the communities' perspective, sustainability implies their ability to recover from technical breakdown in the schemes with the communities' own resources. Thus community members are required to raise funds for O\&M cost. As part of the community management, water facility bank account is required where funds raised for new investment and O\&M are lodged. However, discussions with the WATSAN committees showed that no money was saved in the bank after acquiring the facilities. This was because communities did not regularly contribute towards operation and maintenance but only contributed as and when repairs were needed. After repairs the remaining money (if any) was saved with the chairman of the WATSAN committee. From the households' perspectives, 67.4 per cent of respondents do not know how the remaining money was spent. This often generated conflict when households were required to pay for subsequent repairs. On the other hand, all the WSDBs saved with banks.

Sustainability of facilities is a function of consumer satisfaction with the management of the facilities by the committees. The study indicated that 81.4 per cent of the households were satisfied with the management of the facilities. Factor analysis of consumer satisfaction revealed that water sufficiency, reliability of water supply, trustworthiness of the WATSAN committees, prompt repairs of facilities as and when required, cleanliness of facility (Point Source) sites were the prime indicators for consumers satisfaction. However 11.6 per cent of the households were not satisfied with management because of lack of transparency in the use of borehole money, lack of committee - community interface, irregular flow of water (without explanation), low water pressure (flow rate) as well as lack of enforcement on payment of fees towards repairs. As such, some households were continuously noted for non-payment towards operation and maintenance, though they fetch the water.

There are no regulations on the time of fetching water. Household members can fetch water at anytime of the day or night. This implies that there is no monitoring of the operation in the night and this can result in breakdown of the facilities especially if children are the majority who draw water in the night. The elders however cautioned that fetching water in the night should be avoided as much as possible.

\subsection{Access to Water Services in Nadowli District}

As indicated in Table 2, the main sources of potable water in the District include; pipe systems, boreholes, HDWs (with or without pumps). Hand Dug Well (HDW) includes a well that is properly constructed and has the following components: lined, well head, cover, apron, gutter, and trough or soak away.According to the DWST, majority of the boreholes were constructed between 1973 and 1983 under the then Upper Region Rural Water Supply Project (URRWSP) which was jointly funded by Government of Ghana and Canadian International Development Agency (CIDA). The various potable water facilities as well as their status are shown in Table 2. The non-functional boreholes as indicated in Table 2 can be repaired while the condemned boreholes cannot be repaired. The study revealed that factors responsible for the non-functioning of boreholes as at the time of the survey ranged from extreme low yield, inability to raise funds to acquire spare parts, to lack of access to spare parts. According to the DWST, the condemned boreholes cannot be repaired because the spare parts are so obsolete that, it is difficult to obtain them. The non- functional and condemned boreholes were owned by the community.

\section{Insert Table 2}

Data from the DWST indicated that access to potable water in the District as at December, 2008 was 88.2 per cent of the population which is higher than the regional average of 78 per cent within the same period. In the study communities, 95 per cent of the respondents have access (both physical and economic) to potable water as shown in Table 3. It was found that 5 per cent of the respondents still used unsafe sources of drinking water (See Table 3). The study further investigated the reasons for using unsafe water for domestic purposes (See Table 3). According to the study, in communities where there are boreholes, households paid only when repairs were needed. The cost per head ranged from GH $\phi 0.50$ (US\$0.40) to GH $\phi 4.00$ (US\$3.20), depending on the degree of breakdown. On the contrary, in Nadowli and Daffiama STWS, pay-as-you fetch is practiced by households who do not have household connection. In the study communities, the average distance to a source of potable water was 276 meters though 4.7 per cent of the respondents traveled beyond the maximum distance (500 meters) to draw water. The traveling distance to water sources is influenced by the settlement pattern (disperse). 


\section{Insert Table 3}

In this study, efficiency in accessing water was measured by the time spent in drawing water. In the dry season, the average time spent is 58 minutes though 32.6 per cent of the households spend over two hours to draw water. The average time spent in fetching water in the rainy season is 25 minutes, with only 25.6 per cent of households spending above the average time. Less time is spent in the rainy season because of available alternative sources (such as rivers, hand dug well, dug outs) of drinking water, though they may not be potable.

\subsubsection{Payment for Water Services}

Payment for water services in the point source communities was different from the small town water system. This was because of available alternative sources of water. Households were asked to indicate the amount they paid for water services. Based on the households' response, a follow up question was whether they were willing to pay for the same service if the amount was doubled (For example if a basin of water is increased from GHp5.00/US\$0.04 to GHp10.00/US\$0.08). About 93 per cent of the respondents were willing to pay. However, a female respondent in Nadowli who fetched water from a dug-out for domestic use had this to say;

Before they brought the water system I was asked to pay about GH $₫ 3.00$ (US\$2.40). To me, to pay GH $₫ 3.00$ and get water throughout your life is good. But upon installing the system, I never fetched water free and I cannot continue to pay GHp5.00 per basin. So I resorted to drinking from a well (Unimproved). After all, a similar water source was our only source of water in a farming community in Brong Ahafo Region.

\subsubsection{Communities without Potable Water}

As shown in Table 2, eight communities in the District do not have any form of potable water as at the time of the study. These communities, according to the DWST, have either experienced dry wells or have population less than 100. Besides the small population, the houses are too scattered that getting community consensus on the location of a water facility becomes difficult. Two of these communities (Dunjaang and Orikutuo) were studied. In Dunjaang, the community paid its contribution (5 per cent) and applied for a borehole. Drilling was done three times but none was successful. A fourth drilling and pipe installation was carried out a year ago by Global Water Initiative and Catholic Relief Service (GWI/CRS).

The hydro geology consultant of the project cautioned that, though the fourth drilling was successful, the borehole may be low yielding since the rate of extraction is likely to be more than that of recharge. This is because the start-up yield after pump installation will be 13.5 litres per minute. DWST explained that two factors informed the pipes' installation; i) it meets the minimum yielding requirement of 13.5 litres per minute and ii) the community has no access to potable water. The pump has not been installed and the source of drinking water is a dug out well.

In Orikutuo, households travel an average of 1.4 kilometer to access potable water. This is almost three times farther than the 500 meters approved maximum distance of the NCWSP. The people in Orikutuo contribute towards the operation and maintenance of that facility. A discussion was held with community members on the procedures and conditions for acquiring potable water. They were found to have the ability and willingness to apply for a point source on their own. In both communities, contribution towards capital cost of water is never the reason for lack of potable water.

\section{Conclusion and Recommendations}

The underlying principle of community management is to ensure that the facilities are sustainable once they are installed. This requires some key actors such as water management institutions across levels. These actors have direct and indirect roles in promoting and sustaining community ownership and management strategy. With the actors in place and functioning, ccommunity management of facilities has the potential of further increasing access to potable water services in rural Ghana. With the current trend in access to potable water, Ghana is likely to achieve the MDG target on potable water. Recognising that water is life, communities place emphasis on maintaining the water facilities. This gives a brighter future of sustaining water facilities for the purpose of maximising health benefits. To sustain access to potable water, access to spare parts needs to be improved. Obsolete hand pumps should be replaced with modern ones to ensure easy access to spare parts in case of breakdown. Community members should be given the opportunity to visit other schemes so that they can share problem solving strategies. This could be done through district fora that allow community institutions to visit others to study how they manage their facilities. Accountability is key to a successful management of water facilities. Therefore community institutions must be made accountable to the community members. The DWST can support in implementing this recommendation through regular monitoring. 


\section{References}

Berkoh, C., Hirsch, D., Larbi, E. Leenen, Ntow, S., Jo Smet, F. Marjon, T. (2004). A Report on the feasibility of Public-private partnership for sustainable water supply to the urban poor in Ghana. [Online]. Available: from http://docs.watsan.net/Downloaded_Files/PDF/Berkoh-2004-Feasibility-main.pdf (November 12, 2008).

Brennan, D. (1994). The Politics of Australian Child Care - Philanthropy to Feminism and Beyond. Cambridge UK,

Cambridge University Press.

Conyers, D. (1981). Social Planning in the Third World. Chichester, John Wiley, (Chapter 7).

Community Water and Sanitation Agency (2007a). Community Water and Sanitation Agency Corporate Brochure.

Accra, CWSA.

Community Water and Sanitation Agency. (2007b). Strategic Investment Plan, 2008-2015 \& the Medium-Term Plan, 2008- 2012. Accra, CWSA.

Eguavoen, I. (2008). Changing Household Water Rights in Rural Northern Ghana. England, Palgrave Macmillan Ltd.

Eguavoen, I. (2006). Drinking Water Policy, Water Rights and Allocation Practice in Rural Northern Ghana. Bonn,

Germany, [Online] Available: from http://www.tropentag.de/2006/abstracts/full/134.pdf (January 9, 2008).

Evans, P. and Appleton, B. (1993). Community management today: the role of communities in the management of improved water supply systems. The Netherlands, IRC International Water and Sanitation Centre.

Ghana Statistical Service. (2005). 2000 Population and Housing Census Report. Accra, Ghana, Ghana Statistical Service.

Government of Ghana. (2005). Annual Progress Report, GPRS I. Accra, NDPC Publication

Government of Ghana. (2008). Annual Progress Report, GPRS I. Accra, NDPC Publication

Government of Ghana. (2006a). Ghana Millennium Development Goals, 2006 Report. Accra, NDPC Publications Government of Ghana. (1998). Community Water and Sanitation Agency Act, Act 564.

Hiroko, M. (2008). Sustainability Assessment of National Rural Water Supply Program in Tanzania. Natural Resources Forum, 32:4. [Online]. Natural Resources Forum, Available: from http://www-lacan.upc.edu/publications/files/NRF_RGx_APF_1.pdf (February 12, 2009)

Karikari, K. (1996). Water Supply and Management in Rural Ghana: Overview and Case Studies. Ghana, University of Ghana. [Online] Available: http://www.idrc.ca/en/ev-31158-201-1-DO_TOPIC.html (August 26, 2008)

Kendie, S. B. (2002). Linking Water Supply, Sanitation and Hygiene in Northern Ghana. Cape Coast, Catholic Mission Press.

Korten, D. (1987). Community Management: Asian Experience and Perspectives. West Hartford, Kumarian Press. Laryea, O. N. (1994). Challenges and Prospects of Community Management in Ghana UNPD/GWSC Rural Water and Sanitation Project, Sri Lanka, WEDC Publication

Maganga F.P. and Butterworth J.A. (2002). Domestic Water Supply, Competition for Water Resources and IWRM in Tanzania: A Review and Discussion Paper. Tanzania. Physics and Chemistry of the Earth, Vol. 27, No. 11, 2002 , pp. 919-926, doi: 10.1016/S1474-7065(02)00094-3

McCommon C, Warner D. and Yohalen D. (1990). Community Management of Rural Water Supply and Sanitation Services. Discussion Paper No. 4, p. 49.Washington D.C, UNDP-World Bank.

McGarry M. G. (1991). Water Supply and Sanitation in the 1990s. Geneva Water International, Vol 16. pp. 153-160.

Norgaard, R. B. (1994). Development Betrayed-The End of Progress and a Co-evolutionary Revisioning of the Future, New York, Routledge. 
Rondinelli, D. A. (2006). Public Administration and Development: Decentralizing water supply services in developing countries. Washington D.C, John Wiley \& Sons.

Salim, A. S. (2002). Rural Water Sector Reform in Ghana: A Major Change in Policy and Structure. Water and Sanitation Program-Africa Region (WSP-AF) Nairobi, Kenya. [Online] Available: http://www.sulabhenvis.in/admin/upload/pdf_upload/af_bg_ghana.pdf(June 4, 2008).

Soniya, C and Howard, W. (1997). Combining the Qualitative and Quantitative Approaches to Poverty Measurement and Analysis. Washington DC, World Bank.

WaterAid. (2005). National Water Sector Assessment, Ghana. London, Prince Consort Albert Embankment, London

World Health Organisation. (1996). Community Management of Rural Water Supply and Sanitation System. Points for Practitioners. Geneva, Environment Documentation Centre.

World Health Organisation. (1976). Health Aspect of Human Settlement. Geneva, WHO Publications.

World Health Organisation/United Nations International Children Education Fund. (2000). Global Water Supply and Sanitation Assessment 2000 Report. WHO /UNICEF JMP for Water Supply and Sanitation. New York. [Online] Available: http://www.who.int/water_sanitation_health/monitoring/jmp2000.pdf (February 20, 2008).

World Bank. (2005). Implementation Completion Report on a Credit to the Republic of Ghana for CWSP II in Support of CWSP I, Report. World Bank.

World Bank. (2008). Water and Sanitation Supply: Improving services for the poor. Washington DC, USA, IDA Publications.

Yin, R. K. (1984). Case study research: Design and methods. Newbury Park, CA: Sage

Table 1. Access to Water by Rural Population in Ghana

\begin{tabular}{lcccc}
\hline Region & $\mathbf{2 0 0 5}$ & $\mathbf{2 0 0 6}$ & $\mathbf{2 0 0 7}$ & $\mathbf{2 0 0 8}$ \\
\hline Ashanti & $50.2 \%$ & $63.06 \%$ & $62.82 \%$ & $72.95 \%$ \\
\hline Brong Ahafo & $46.6 \%$ & $52.00 \%$ & $54.44 \%$ & $53.51 \%$ \\
\hline Central & $36.5 \%$ & $46.36 \%$ & $48.87 \%$ & $44.35 \%$ \\
\hline Eastern & $53.2 \%$ & $47.12 \%$ & $49.89 \%$ & $58.88 \%$ \\
\hline Greater Accra & $53.0 \%$ & $50.96 \%$ & 57.23 & $59.03 \%$ \\
\hline Northern & $47.9 \%$ & $58.12 \%$ & $59.53 \%$ & $57.97 \%$ \\
\hline Upper East & $69.0 \%$ & $51.27 \%$ & $50.81 \%$ & $52.24 \%$ \\
\hline Upper West & $93.1 \%$ & $67.18 \%$ & $78.24 \%$ & $76.76 \%$ \\
\hline Volta & $61.3 \%$ & $50.99 \%$ & $50.81 \%$ & $54.26 \%$ \\
\hline Western & $43.7 \%$ & $41.53 \%$ & $40.93 \%$ & $41.27 \%$ \\
\hline Total & $\mathbf{5 2 \%}$ & $\mathbf{5 2 . 8 6 \%}$ & $\mathbf{5 4 . 8 6 \%}$ & $\mathbf{5 7 . 1 4 \%}$ \\
\hline
\end{tabular}

Source: Government of Ghana, 2005 \& 2008 
Table 2. Water Facilities by Area Councils in Nadowli District

\begin{tabular}{|c|c|c|c|c|c|c|c|c|c|c|}
\hline \multirow[b]{3}{*}{ AREA COUNCILS } & \multirow{3}{*}{ 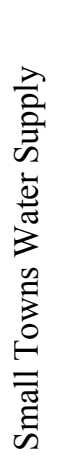 } & \multicolumn{6}{|c|}{ Boreholes } & \multirow{2}{*}{\multicolumn{2}{|c|}{$\begin{array}{l}\text { Hand Dug } \\
\text { Wells (Public) }\end{array}$}} & \multirow{3}{*}{ 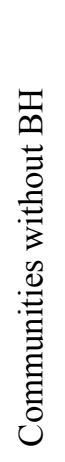 } \\
\hline & & \multicolumn{2}{|c|}{ Institutional } & \multicolumn{4}{|c|}{ Public } & & & \\
\hline & & 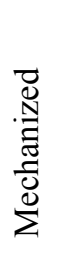 & 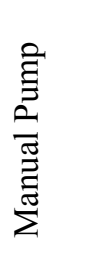 & 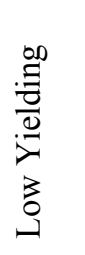 & 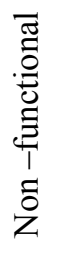 & 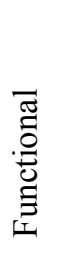 & $\begin{array}{l}\overrightarrow{0} \\
\text { İ } \\
\overline{0} \\
\overline{0}\end{array}$ & 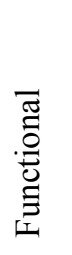 & 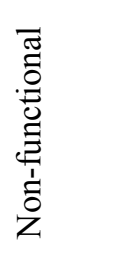 & \\
\hline 1. Issa & 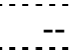 & 1 & 3 & 5 & 7 & 31 & 3 & 3 & 8 & 1 \\
\hline 2. Takpo & 1 & $\begin{array}{ll}\cdots \\
\therefore-\end{array}$ & 1. & 8 & 1 & 38 & 1. & - & 7 & 1. \\
\hline 3. Daffiama & 1 & 1 & 8 & 7 & 2 & 24 & 2 & 2 & 2 & 1 \\
\hline 4. Bussie & $\begin{array}{ll}-- \\
-\therefore\end{array}$ & $\therefore$ & 2 & 15 & 4 & 18 & 1 & 3 & 6 & - \\
\hline 5. Cherikpong & $\begin{array}{ll}-- \\
-\cdots\end{array}$ & 1 & 2 & 8 & - & 30 & - & 6 & 1 & - \\
\hline 6. Nadowli & 1 & 4 & 5 & 22 & 3 & 39 & 1. & 2 & 2 & 3 \\
\hline 7. Kaleo & $\begin{array}{l}\cdots- \\
-\cdots\end{array}$ & 1 & 1 & - & 6 & 20 & 2 & 品 & 5 & - \\
\hline 8.Jang & $\therefore$ & $\therefore$ & 3 & - & 7 & 30 & 5 & 10 & 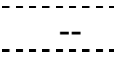 & $\therefore$ \\
\hline 9. Sombo & $\therefore$ & $\therefore$ & 1 & 7 & 1 & 28 & 1 & 10 & 5 & - \\
\hline 10. Sankana & $\therefore$ & $\therefore$ & 1 & 1 & 1 & 14 & - & - & 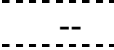 & 2 \\
\hline TOTAL & 3 & 8 & 27 & 73 & 32 & 272 & 16 & 36 & 36 & 8 \\
\hline
\end{tabular}

Source: Field Survey, April 2009

Table 3. Sources of Drinking Water in the Study Communities

\begin{tabular}{|l|c|c|l|c|c|}
\hline \multicolumn{3}{|c|}{ Access to potable water } & \multicolumn{3}{c|}{ Reasons for not using borehole/pipe water } \\
\hline Facility & Frequency & Per cent & \multicolumn{1}{|c|}{ Reasons } & Frequency & Per cent \\
\hline Borehole & 119 & 74.4 & Do not like mode of payment & 2 & 25.0 \\
\hline Pipe Borne & 33 & 20.6 & Poor quality/taste relative to others & 1 & 12.5 \\
\hline Stream/River & 8 & 5.0 & too far away relative to others & 2 & 25.0 \\
\hline & & & unreliable relative to others & 3 & 37.5 \\
\hline \multicolumn{1}{|c|}{ Total } & $\mathbf{1 6 0}$ & $\mathbf{1 0 0}$ & & $\mathbf{8}$ & $\mathbf{1 0 0}$ \\
\hline
\end{tabular}

Source: Field Study, April, 2009. 


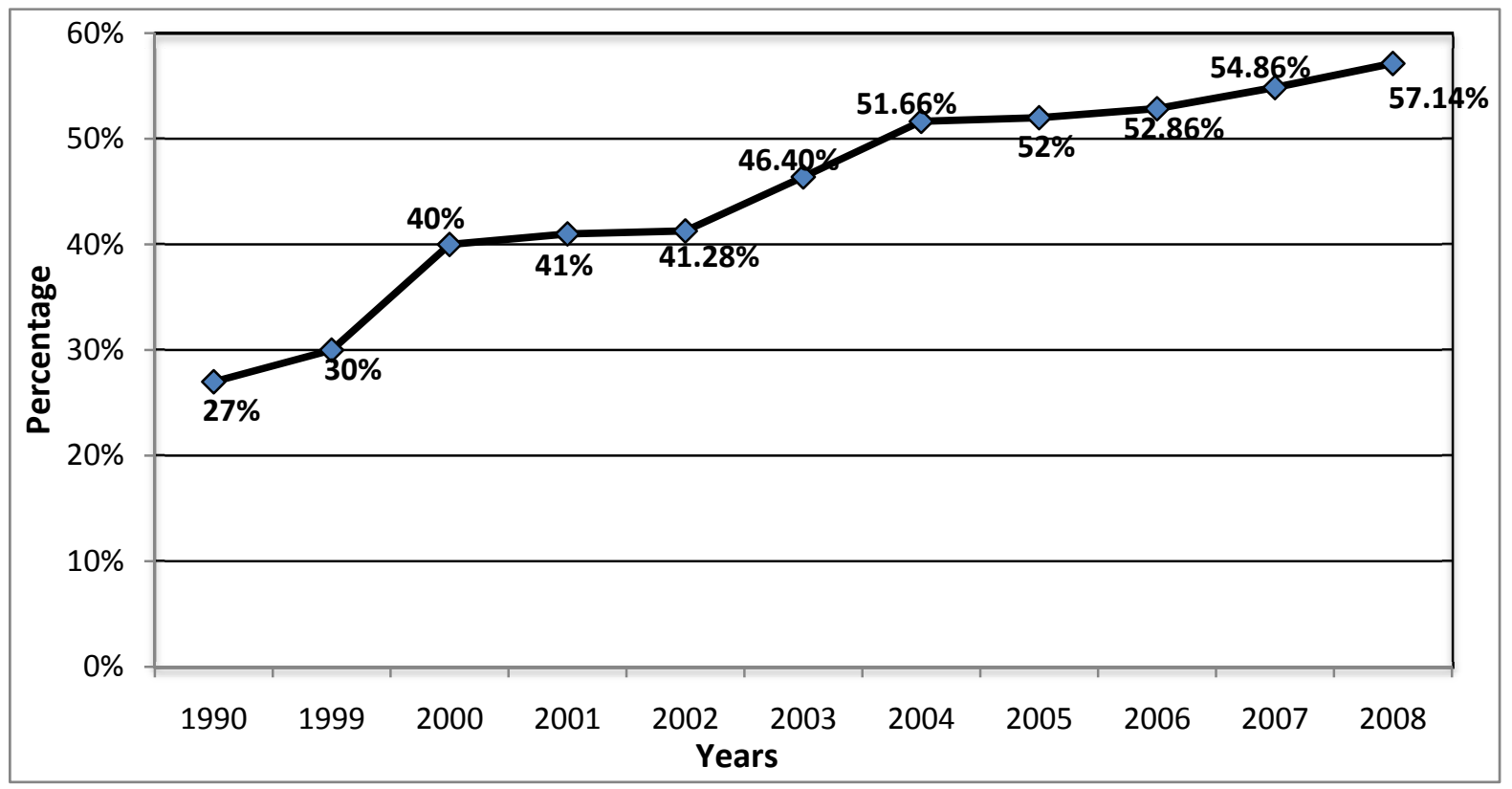

Figure 1. Trends in Rural Potable Water

Source: 2005 \& 2008 GPRS Annual Progress Reports 